\title{
TRISTEZA DO JECA, CANTO DO CAIPIRA
}

\section{THE JECA'S SADNESS, IN A COUNTRY SONG}

\author{
Celso Donizete Cruz \\ UFS - Universidade Federal de Sergipe
}

\begin{abstract}
Resumo: Análise da canção "A tristeza do jeca", de Angelino de Oliveira, à luz do modelo descritivo proposto pela semiótica da canção. Percorridos os estratos que, segundo o modelo, geram o sentido nessa canção específica, identifica-se, tanto na melodia quanto na letra, o poder consolador do canto do caipira, resultante de um estado passional misto de tristeza, resignação e saudade, cujas causas são sugeridas, porém não explicitadas.
\end{abstract}

Palavras-chave: semiótica textual; semiótica da canção; música popular brasileira; música caipira.

Abstract: Analysis of the song "A tristeza do jeca" by Angelino de Oliveira, under the light of a descriptive model proposed by the song semiotics. By unveiling the strata that, according to this model, generate meaning in this specific song, we can find in the melody as well as in the lyrics, the consoling power of the country song resulting from a passionate frame of mind which is a mixture of sadness, resignation and homesickness whose causes are only suggested but never completely explicited.

Keywords: textual semiotics; song semiotics; Brazilian pop music; country music.

este canto que sente e sai vem das cordas do coração 


\section{Introdução}

A canção, desde o título "A tristeza do jeca", anuncia os seus propósitos. Querse contar (e canta-se) o estado passional de um ser-personagem, o jeca. Temos a representação e a exposição de uma tristeza, e é o próprio jeca quem expõe essa sua condição e, desse modo, expõe-se.

O discurso escolhido para a manifestação dessa exposição, a canção, presta-se à maravilha para tanto: não só destaca o estado passional tematizado como se deixa contaminar por ele e, assim contaminada, insta sub-repticiamente para que o ouvinte também se contamine. Essa canção em particular é o espaço de manifestação de um pathos, de uma dor que, em se manifestando dessa forma, alcança mitigação, para alívio do sujeito que a suporta. Há um processo catártico implicado. $\mathrm{O}$ fazer que deflagra a catarse (em quem canta, e porventura em quem escuta) é o canto. Detalhando o processo, pode-se dizer que é o canto que intensifica um estado já coalhado de tristeza, e essa intensificação, levada ao ápice, desfaz-se em lágrimas. $\mathrm{O}$ canto é o agente que deflagra o choro de alívio, purificador. Tal é o poder de consolação atribuído à canção. Já dizia o ditado: "quem canta seus males espanta".

Todos esses conteúdos e efeitos de sentido aventados num primeiro relance, penso melhor entendê-los e explicá-los, com o auxílio do modelo semiótico: para a análise da letra, o modelo canônico, em sua variante tensiva, e para a melodia o modelo proposto pela semiótica da canção. Inicialmente a letra da canção é decomposta em seus estratos gerativos de sentido, isto é, seus níveis discursivo, narrativo e tensivo, e em seguida, com o trânsito possibilitado pelo nível tensivo, procede-se à analise da melodia. Na parte final, levando-se em conta os resultados da análise, comentam-se ligeiramente duas opções de realização da canção, adotadas respectivamente pelos intérpretes Pena Branca \& Xavantinho e Passoca.

\section{A letra}

\section{A tristeza do jeca}

Nestes versos tão singelos

Minha bela, meu amor

Pra você quero contar

O meu sofrer e a minha dor

Eu sou como um sabiá

Quando canta é só tristeza

Desde o galho onde ele está

(Angelino de Oliveira)

Nesta viola eu canto e gemo de verdade

Cada toada representa uma saudade

Eu nasci naquela serra

Num ranchinho beira chão

Todo cheio de buraco

Onde a lua faz clarão

Quando chega a madrugada

Lá no mato a passarada

Principia um barulhão

(Refrão) 
CASA, Vol.6 n.1, julho de 2008

Lá no mato tudo é triste

Desde o jeito de falar

Quando riscam na viola

Dá vontade de chorar

Não tem um que cante alegre

Todos vivem padecendo

Cantando pra aliviar

(Refrão)

Vou parar com a minha viola

Já não posso mais cantar

Pois o jeca quando canta

Tem vontade de chorar

$\mathrm{O}$ choro que vai caindo

Devagar vai se sumindo

Como as águas vão pro mar

\section{Análise da letra}

\section{- Nível discursivo}

\section{Isotopias}

É possível detectar quatro isotopias principais. Uma delas está ligada ao mundo rural. Os lexemas "viola", "mato", "serra", "ranchinho beira-chão", "sabiá", "passarada" instauram como cenário o universo do caipira (um dos possíveis sinônimos de "jeca"). Em paralelo, ocorre a reiteração de lexemas que denotam um estado passional disfórico: "tristeza", "sofrer", "dor", "triste", "gemo", "padecendo", "saudade", "choro". Outro grupo tem como tema o canto: "versos", "cantar", "viola", "toada". E a última isotopia apresenta o sema "água" figurativizado nos lexemas "choro", "chorar", "águas", "mar".

Alguns lexemas participam dos dois grupos, caso de "sabiá" e "viola", que pertencem tanto ao universo caipira quanto ao universo do canto, e "choro", do grupo das águas e do grupo da dor. As associações entre os grupos são também um artifício da vontade do enunciador: o mundo rural se associa à dor, que por sua vez se associa ao canto, que por sua vez se associa ao choro. Com a intervenção do enunciador, os eixos associativos, o paradigmático e o sintagmático, chegam a um encaixe:

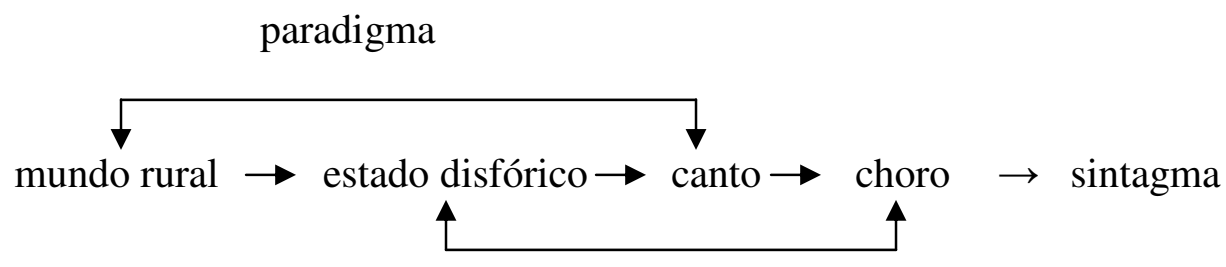

Esquema I: Eixos associativos.

Pode-se mesmo dizer que há um desdobramento de universos temáticos possibilitando uma abertura para o encaixe: o mudo rural abarca o estado disfórico e é ao 
mesmo tempo abarcado por ele. Os dois universos imbricam-se. $\mathrm{O}$ encaixe proporciona o máximo de aderência possível na aproximação de dois corpos. E é assim que os dois mundos se fundem no corpo do enunciador, que os subsume. ${ }^{1}$

\section{Debreagens}

Uma alternância de engates e desengates traduz o ritmo de debreagens nessa canção. O refrão sintetiza o movimento. No primeiro verso, há a presentificação de um euaqui-agora ("nesta viola, eu canto e gemo de verdade"), uma debreagem enunciativa, portanto. No último, o engate é no enunciado: "cada toada representa uma saudade".

Essa alternância intensa no refrão repercute extensamente na primeira e na quarta parte da canção. Na primeira parte, o quarteto inicial promove uma debreagem enunciativa e o terceto final, uma debreagem enunciva. $\mathrm{Na}$ quarta parte, o terceto final confirma a debreagem enunciva, mas o quarteto inicial se subdivide, com o engate na enunciação nos dois primeiros versos e o engate no enunciado nos dois últimos. É interessante ver esse efeito de enunciação mais de perto. Parece operar-se aqui o que Diana Luz Pessoa de Barros chama de "procedimento oposto à desembreagem enunciva ou enunciativa, denominado embreagem".

A embreagem apresenta-se como uma operação de retorno de formas já desembreadas à enunciação e cria a ilusão de identificação com a instância da enunciação. A enunciação finge recuperar as formas que projetou fora de si. Nega-se o enunciado e procura-se produzir o efeito de suspensão da oposição entre os atores, o espaço e o tempo do enunciado e os da enunciação (BARROS, 2001, p. 77).

$\mathrm{Na}$ quarta parte, portanto, flagra-se um procedimento de embreagem, cujo fim é produzir a "suspensão da oposição" entre os elementos do plano da enunciação e do plano do enunciado. Mediante a análise desse dado intenso, a astúcia enunciativa da canção pode ser desvendada.

Há na embreagem o desdobramento da enunciação em enunciado e o consequiente retorno do enunciado à enunciação. O retorno provoca um curto-circuito no processo, ao propor a identificação plena do "eu" da enunciação ao "ele" do enunciado ("jeca"), com a fusão também de seus respectivos espaços (aqui/lá) e tempos (agora/então). São assim redobrados os laços metonímicos implícitos, que ligam o enunciado à instância de enunciação. E por outro lado, explicita-se uma vez mais a presença da enunciação no enunciado, uma vez que a primeira já havia sido explicitada pela debreagem enunciativa.

Se estendermos agora esse raciocínio para a análise dos outros dois momentos em que a passagem de uma debreagem a outra tem lugar, veremos que o mesmo procedimento de reversão do enunciado está presente, porém atenuado ao assumir a forma discursiva da reflexão ou, mais precisamente, da auto-reflexão. Os efeitos da reversão são atenuados, porque há uma explicitação do que é implícito na reversão, isto é, dos nexos que relacionam enunciado e enunciação. $\mathrm{O}$ enunciado da primeira parte nada mais é que o desdobramento reflexivo do narrador, que emite um juízo de valor sobre si mesmo ("eu sou como"). E no refrão, a debreagem enunciva aciona um juízo que incide sobre o próprio discurso ("cada toada representa"). O jogo de explicitações está ligado a esses mecanismos de

\footnotetext{
${ }^{1}$. E não seria possível ver na fórmula do encaixe a projeção da função poética tal como a propôs Jakobson?
} 
reversão e auto-reflexão, que têm diferenças apenas de grau: a reversão é a aproximação direta, descontínua, a auto-reflexão preserva os nexos, operando por continuidade.

O desenvolvimento discursivo confirma a opção preferencial pela continuidade, pela manutenção dos liames, daí a presença das comparações na primeira e na quarta parte. As partes intermediárias, em cujo interior não ocorrem desengates, respondem como enunciados ao mesmo movimento de auto-reflexão: é o narrador falando de suas origens como forma de falar de si, novamente com a manutenção dos nexos. Há ainda a considerar, no refrão, o metadiscurso implicado. O metadiscurso comparece quando o discurso volta-se sobre si mesmo, ou seja, reflexiona, o que é um modo de se auto-interpretar e guiar a interpretação do enunciatário, para que este entenda, do ponto de vista do enunciador, o que está sendo representado.

Outro ponto a destacar nesse movimento de reversão e auto-reflexão é que, ao efetuar, como colocou Barros (id. ibid.), a suspensão da oposição entre os espaços (aqui/lá) e os tempos (agora/então) da enunciação e do enunciado, o procedimento abre caminho para a manifestação da figura da saudade, que supõe justamente essa superação espaço-temporal. Volto ao assunto mais adiante.

Todas essas manipulações discursivas ligadas à instância da enunciação têm por escopo principal criar um efeito de "realidade", e assim atribuir maior valor de verdade ao que é dito. A debreagem enunciativa de primeiro grau, ao explicitar a instância de enunciação implícita em qualquer discurso, evidentemente repercute no universo da canção, "em que se supõe necessariamente a voz de um intérprete contando (ou cantando) o conteúdo da letra aqui e agora" (TATIT, 2001, p. 43 - grifos no original). Na canção, a instância da enunciação, corpo ancorado no real, ao ser explicitada, traz para o discurso a sua marca de realidade: o efeito criado é de que a cena está se passando "ao vivo". Com a reversão do enunciado, a atenção volta a incidir sobre a cena presentificada, e nesse caso o resultado parece ser sempre a exibição do estado passional do sujeito da enunciação (enunciador/narrador) - e é da autenticidade deste último que depende, em última instância, o valor de verdade do enunciado e da enunciação.

Em "A tristeza do jeca", não poderia ser diferente. As estratégias enunciativas nessa canção condizem com o propósito de exposição de estado passional ao vivo, com valor de "verdade".

\section{- Nível narrativo}

\section{Competências}

Considerando-se as posições do narrador ("eu”) e do narratário ("minha bela, meu amor", "você") explicitadas no plano do enunciado, tem-se, na canção sob análise, uma situação de comunicação que envolve os actantes destinador e sujeito-destinatário. É o momento em que o destinador, mediante um fazer persuasivo, "busca a adesão do destinatário". O destinador quer fazer-fazer, entretanto, antes disso cabe a ele fazer-crer, isto é, "fazer com que o destinatário, ao exercer o fazer interpretativo que lhe cabe, creia ser verdadeiro o objeto apresentado, o discurso do outro e o próprio destinador" (BARROS, 2001 , p. 37 - grifos no original). O que o destinador precisa, para fazer-fazer, é estabelecer com o destinatário um acordo de confiança e crença, um contrato fiduciário, em suma.

É essa a situação que se apresenta inicialmente na canção em análise. $O$ narrador anuncia seu propósito de expor ("quero contar") o seu estado passional ("o meu 
sofrer, a minha dor"). ${ }^{2}$ Seu objetivo, ao que tudo indica, é despertar a empatia do narratário, na tentativa de estabelecer com este um contrato fiduciário e assim, porventura, levá-lo a um fazer que a princípio pode ser entendido como "comoção". Para isso é fundamental que o narratário creia na "verdade", tanto do que é exposto quanto do modo de exibição.

Um dos recursos que o narrador usa para atribuir veracidade ao seu discurso é afirmar explicitamente o seu fazer persuasivo e o seu estado ("nesta viola eu canto e gemo de verdade"). Acontece que o grau de veridicção de uma afirmação dessas fica comprometido, porque ela provém justamente da fonte que solicita crença e confiança. Um recurso mais eficaz para dar autenticidade ao que é dito parece ser a submissão a um valor de verdade maior, passar para um "plano axiológico, representativo de um sistema de valores comunitários, de onde emanam forças e influências de um poder preestabelecido, hierarquicamente superior, um lugar de decisão caracterizado como instância do destinador" (TATIT, 2001, p. 30 - grifos no original). Ao narrador interessa então abdicar da função de destinador e apresentar-se como sujeito, por isso ele se desdobra. ${ }^{3}$ A verdade do seu estado passional, bem como a verdade do seu fazer, são remetidas às suas origens. É "por ser de lá" que ele é assim. Esse procedimento de busca de isenção para a manifestação de uma "verdade transcendente" tem seu ponto de desdobramento máximo na quarta parte da canção, quando, ao justificar a interrupção do seu fazer, o narrador, por meio da embreagem, argumenta com a vontade do personagem/sujeito: "vou parar minha viola / já não posso mais cantar / pois o jeca quando canta / tem vontade de chorar".

\section{Estado passional}

O sujeito do plano do narrado é o ser que sofre conformado, resignado à sua dor. A tristeza, estado passional disfórico, anuncia um estado de disjunção no plano narrativo. Competiria ao sujeito movimentar um fazer que levasse à transformação desse estado de disjunção em seu contrário, a que se seguiria um estado de euforia. Não é o que acontece nesta canção. A disforia radical que contamina o cenário parece minar no sujeito qualquer tentativa de ação nesse sentido. A aquisição ou não de um objeto de valor não vem em primeiro plano. ${ }^{4}$ Há, porém, um movimento de intensificação que aciona (ou é acionado por) um fazer que leva o estado de disforia ao máximo de tensão suportável pelo sujeito. É quando a disforia é tanta que insta uma reação, e ela vem em forma de pranto, uma reação somática que significa justamente impossibilidade de instauração de um programa de liquidação da falta (FONTANILLE ; ZILBERBERG, 2001, p. 283).

Esse estado de disjunção, dado o seu aspecto a priori irremediável, responde muito bem à manifestação da figura da "saudade", que tem presença importante na canção. Podemos decompor essa figura em uma sintaxe narrativa. A saudade corresponde a uma disjunção atual que chegou a ser uma conjunção no passado, é a manifestação de uma vontade

\footnotetext{
2. Para realizar o que deseja é preciso que o narrador, aqui na função de destinador, não apenas queira, mas também deva, saiba e possa fazer, isto é, que tenha as competências para atingir seus objetivos. Na medida em que canta, porém, demonstra que não lhe faltam essas competências: ao enunciar a sua vontade, o seu fazer já está em curso.

3. E daí os vários engates e desengates, na enunciação e no enunciado. No plano da enunciação, o narrador é sujeito de um fazer persuasivo; no plano do enunciado, é o jeca sofredor.

${ }^{4}$. Mas não é o caso do narrador em função de destinador persuasivo. Desse ângulo, sua ação é um passo na busca de (re)conciliação entre sujeito e objeto, cuja disjunção seria a origem da disforia que toma conta de todo o universo do narrado.
} 
de reestabelecer essa conjunção e é, em contrapartida, a manifestação da consciência de que essa conjunção, no presente, é impossível, a não ser no plano da evocação, quando se procura justamente simular, presentificar o passado no presente. ${ }^{5}$ Como vimos, os recursos enunciativos empregados servem justamente para suspender essa oposição temporal.

Pela figura da saudade, pode-se ver o narrador em situação de exílio (e o "sabiá", digno representante da "Canção do exílio", é sugestivo nessa suposição), e assim teríamos uma causa segura para o estado passional que ele exibe e diz sofrer. O interessante, porém, é que aqui não está explícita a carga euforizante que, em casos de exílio, normalmente é conferida ao local de origem. Nesses casos, em geral o sujeito lamenta o afastamento exaltando os valores do seu locus original, em detrimento dos valores do lugar atual. Essa exaltação reafirma os valores eufóricos, ainda que no plano do imaginado, da conjunção perdida.

Em "A tristeza do jeca", dada a sobreposição do aqui e do lá, isso não é possível. O recurso de suspensão do tempo, para a manifestação da saudade, suspende também as oposições de espaço. E o estado de disforia do narrador no espaço presente invade a projeção imaginada do espaço passado que, em sendo disfórica, não chega a caracterizar um estado de conjunção com o objeto. As razões da disforia vão além das origens do ser que sofre. A saudade então, esvaziada de seu objeto, passa a ser uma figura de reforço disfórico. $\mathrm{O}$ sujeito conserva da saudade só o sentimento de perda a ela associado.

Pode-se dizer mais. É possível afirmar que saudade aqui é tratada como uma via de mão dupla. Ao trazer o passado para o presente, deixa o caminho aberto para a passagem do presente da enunciação para o passado do enunciado. Por essa via o sujeito remete-se ao lugar de onde veio ("Eu nasci naquela serra") e de cujo estado ele é representante ("Lá no mato tudo é triste"). O estado de disjunção é dado como atributo de todos do lugar ("Não tem um que cante alegre"). E é dessa forma que a saudade é aproveitada como veículo de transporte, no esforço do sujeito para isentar-se, por desdobramento, e para dar autenticidade ao seu estado e ao seu discurso.

A saudade também é associada ao fazer do sujeito ("Cada toada representa uma saudade"). Ela comparece acoplada ao canto e, em comunhão com este, faz o sujeito lembrar um estado de disjunção perene, que o acompanha desde as origens. A força de um anti-sujeito ou de um antidestinador desconhecido é tal, que esconde do próprio sujeito o objeto de valor que deveria buscar. Assim, ficam bloqueadas as forças de reação e, como consequiência, não se cumpre um percurso transformador de estado. Pelo contrário, o mecanismo da saudade e do canto reitera o programa narrativo de estado. A reiteração gera o acúmulo e conduz o estado de disforia ao limite. Não sendo suficientes para provocar a transformação, a saudade e o canto servem, contudo, como válvulas de escape. A conscientização que trazem não leva à reação, mas à reflexão, à resignação, e o resultado é a catarse, forma de suportar um estado disjuntivo sem perspectiva de conciliação. Repare-se, na comparação que fecha a letra, a necessidade de justificar a não-reação, o conformismo, pela ordem natural das coisas: "como as águas vão pro mar", como sempre foi (e, supõe-se, sempre haverá de ser).

Portanto, se há algum movimento de transformação envolvido na canção, ele não chega a transformar o estado disjuntivo. Diferente do percurso da catarse, cujo início e fim são explicitamente anunciados (vide a primeira e a quarta parte), o programa narrativo de

\footnotetext{
5. Para os propósitos da análise, essa configuração sumária é suficiente. Há ainda gradações nesse sentimento, de acordo com a possibilidade/impossibilidade de retorno efetivo da conjunção, o contexto da perda de conjunção etc., porém a tentativa de esboço de um arco tensivo que dê conta das várias sutilezas implicadas na figura da saudade está além do escopo deste trabalho.
} 
estado tem como marca aspectual a duratividade: parece não ter começo, e parece que não vai ter fim. Acontece que essa disforia, mesmo irremediavelmente presente, tem gradações. A permanência em um mesmo estado disfórico intensifica o sentimento de dor, até o transbordamento. O sujeito vive à beira do limite em que o transbordar é inevitável. A passagem desse limite está associada ao canto ("Quando riscam na viola dá vontade de chorar", "Pois o jeca quanto canta tem vontade de chorar"), que é justamente a representação do estado do sujeito (a representação de sua saudade desesperançada, de sua tristeza) no plano do narrado, e o fazer do narrador (seu discurso) no plano da narração. Esse fazer é um discurso que (se)explicita, que (se)reitera e leva, por saturação, à purificação ou esvaziamento.

Nesse sentido, o canto é que é o destinador, só que ele não dá ao sujeito as competências para a transformação do estado de disjunção, apenas alívio dos sintomas do estado passional ("Todos vivem padecendo / Cantando pra aliviar"). Em outras palavras, o canto do caipira leva à implosão e não à explosão. E se ao narrador, para dar maior autenticidade ao discurso, convém abdicar da posição de destinador de si mesmo, não surpreende que delegue esse poder ao canto, destinador impessoal e, por isso mesmo, acessível a toda a coletividade.

Assim considerado, pois, o canto é o grande destinador da canção. É ele o fazer persuasivo proposto pelo narrador e o fazer catártico que atua sobre o estado passional do sujeito. No entanto, não é um fazer que independa de um corpo, pois só pode se manifestar por uma voz. E o corpo que manifesta o canto, em contrapartida, contamina-o com seu estado de disjunção. Pode-se ir além, e dizer que o canto é a expressão do sujeito, quando intensificada. Há uma sugestão desse sentido na terceira parte da canção: a expressão cotidiana, "o jeito de falar", já é prenhe de tristeza; "quando riscam na viola", isto é, quando o canto é convocado, a tristeza da expressão transborda. Deve-se lembrar que a matriz do canto, na canção popular, é a fala. Pode-se dizer que na canção o canto estabiliza e ordena as inflexões caóticas da fala (cf. TATIT, 1996, p. 11 - 12). Pois é assim, por dar estabilidade a uma expressão disfórica, que o canto leva a emoção ao limite, ou seja, intensifica o estado, levando à ruptura, à comoção. $\mathrm{O}$ canto é o destinador da catarse, único percurso que se cumpre no nível narrativo, percurso de um fazer que atua no e pelo sujeito, no e pelo narrador/cantor e, por força da autenticidade deste, pode vir a atuar no narratário/ouvinte.

Há, pois, em curso na canção, dois espetáculos. O programa narrativo de estado, espetáculo do sujeito que expõe um estado passional ligado à coletividade da qual faz parte (e, portanto, também é o seu), e o percurso da catarse, espetáculo de um discurso que, ao intensificar a paixão, promove o pranto. $\mathrm{O}$ ator que assume o discurso dessa canção transita por vários papéis: é o narrador que quer atuar sobre o narratário mediante a exposição de seu estado passional, é o sujeito exposto que suporta uma situação perene de disforia e é o ser (narrador/enunciador) que dá voz ao grande destinador impessoal que provoca a catarse no corpo que o abriga (e, quem sabe, no corpo que o escuta).

\section{- Nível tensivo}

O sujeito vem de um estado de não-conjunção e encontra-se estagnado em estado de disjunção. Em nenhum momento, desse ponto de vista, ocorre a não-disjunção que prenuncia a conjunção, quando enfim teríamos um percurso completo de transformação de estado. Como sugerido, a disjunção é durativa e ilimitada. Seus limites incoativos (nãoconjunção) perdem-se no passado, e não há previsão de estabelecimento de limites terminativos (não-disjunção) no futuro. Nesses pontos, o percurso é abortado. O máximo que 
o sujeito logra atingir é voltar, via saudade, para a etapa de não-conjunção, que o devolve ao ponto de partida. Tem-se então o seguinte quadro tensivo, síntese do programa narrativo de estado:

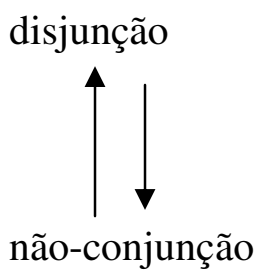

conjunção

não-disjunção

Esquema II: Quadro tensivo I:

Entretanto, no interior do estado, acoplado ao programa narrativo, há um percurso que se cumpre exatamente por causa do aspecto durativo da disjunção. A reiteração do estado de disforia conduz ao máximo de tensão e provoca uma reação de distensão e relaxamento. Pode-se equacionar o processo a partir das figuras do canto, da dor, do choro e do alívio, dispostas no quadrado tensivo.

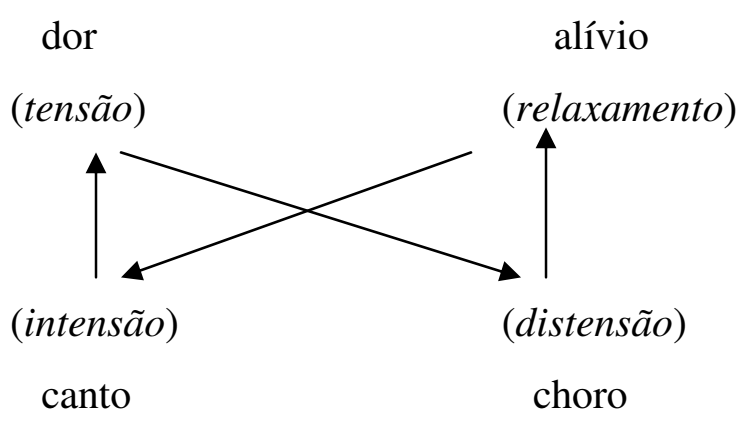

Esquema III: Quadro tensivo II.

Repare-se que esse percurso não lida com grandezas, mas com intensidades. $\mathrm{O}$ fazer que deflagra o processo é decorrência de (e remédio para) uma tensão acumulada, ou seja, intensificada. Pode-se dizer que há em jogo uma só grandeza, que é insuflada - por dentro - até o limite e encontra uma saída num fazer que acolhe a tensividade num corpo que transborda. É esse, creio, o percurso da cartase. De volta ao programa narrativo, o sujeito é remetido para a etapa imediatamente anterior - assim alivia-se da carga disfórica; mas, como não passou para uma nova etapa, pelo contrário, voltou atrás, seu esvaziamento já está comprometido com o conteúdo disfórico virtual associado à próxima etapa a ser atualizada.

No plano dos valores emissivos/remissivos (que afirmam ou negam a velocidade e a duração dos percursos), a dor representa a "parada" e o choro, a "parada da parada", que leva ao alívio ("continuação"). Mas nesse ponto o percurso do fazer catártico se abre para o percurso de estado original. Novamente entra em cena a disjunção ("parada"), continuamente alimentada por uma situação de contrariedade ("parada da continuação") inexorável e inexpugnável.

É esse o elo que liga, na ida e na volta, a passagem do estado passional para o fazer catártico. E assim esse fazer - que é o discurso, que é o canto - deflagra o seu próprio percurso. A "parada da parada" do programa corresponde à "parada da continuação" do percurso. O sujeito do estado portanto, não vendo saída, opta e é cooptado por um percurso simulado no interior da "parada", percurso que lhe serve de consolo. Ao final do percurso da 
catarse, o sujeito se vê livre do sentimento disfórico, mas está ainda indissoluvelmente ligado às origens obscuras dessa disforia, de modo que se pode dizer que ele é novamente remetido à "parada da continuação", que o leva à "parada" e assim por diante. A ausência de percurso narrativo transformador é a condição da duração do estado. E é nesse processo que a tristeza, apensa ao mundo do jeca, chega ao canto do caipira, que a absorve e intensifica, isto é, traz à tona o sentimento de dor introjetado no corpo que convoca o canto, provocando o transbordar da emoção represada e trazendo a anestesia.

\section{A melodia}

Versão básica ${ }^{6}$

\begin{tabular}{|c|c|c|c|c|c|}
\hline \multicolumn{3}{|c|}{ versos } & \multicolumn{3}{|c|}{ cê que } \\
\hline \multicolumn{2}{|c|}{ nestes tão } & mor & pra vo & ro & dor \\
\hline & $\sin$ & bela meu & & con & frer a mi \\
\hline & gelos mi & $a$ & & tar o meu & nha \\
\hline & & & & $\mathrm{s}$ & \\
\hline
\end{tabular}

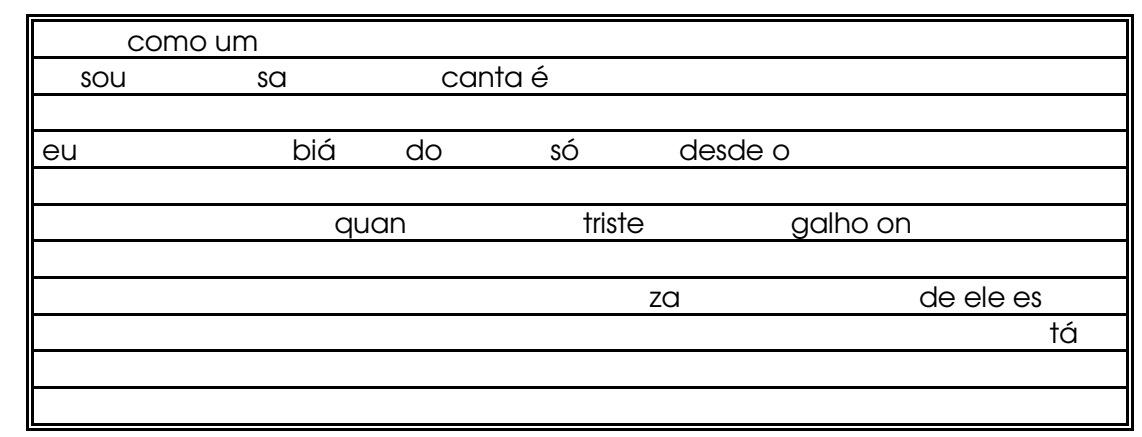

\begin{tabular}{||lll||}
\hline \multicolumn{4}{|c|}{} & \\
\hline \\
\hline
\end{tabular}

Gravações utilizadas: vide Referências.

\footnotetext{
${ }^{6}$. Os diagramas utilizados pela semiótica da canção descrevem os contornos melódicos da letra, sugerindo a melodia. "Cada espaço corresponde a um semitom e seu conjunto, ao campo integral de tessitura utilizado pela canção” (TATIT; LOPES, 2003, p. 100).
} 


\section{Análise da melodia}

A opção geral é pela desaceleração e promoção dos valores emissivos, que confirmam a duração. $\mathrm{O}$ que se mantém é o estado de disjunção, cuja marca aspectual nessa canção, como vimos, é a duratividade. Temos assim perfis melódicos que investem na extensão e na tonalização. Como no primeiro perfil delineado:

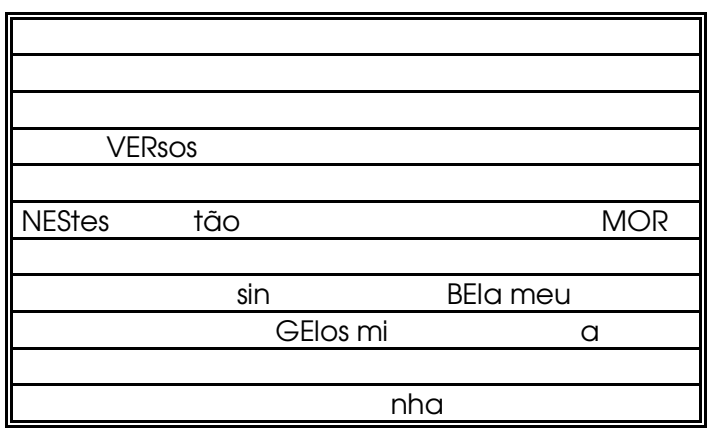

Trata-se de um perfil extenso, cujas tonalizações reforçam a duração. $\mathrm{O}$ ouvinte é instado a acompanhar o perfil em toda a sua extensão. São essas as marcas que normalmente prefiguram a paixão. Temos, portanto, sob esse ponto de vista, de acordo com a semiótica da canção, um procedimento de passionalização. ${ }^{7}$

Nos outros perfis, o procedimento se repete, embora na segunda parte da melodia haja um ligeiro abrandamento das tonalizações, dada talvez a grande extensão do perfil. Nesse ponto detecta-se um leve traço de aceleração. É que a duração dos valores emissivos, ligados à desaceleração, já implica o despertar dos contrários, os valores remissivos da aceleração. E é assim que a manutenção do procedimento de passionalização conduz à tematização. ${ }^{8}$ Esta decorre daquela, intensa e extensamente. E é essa decorrência, que pode ser traduzida superficialmente como uma alternância, que promove o equilíbrio entre os dois procedimentos de estabilização melódica harmonizados em "A tristeza do jeca".

Vejamos mais de perto o primeiro perfil melódico. Ele inicia por um movimento conjunto e acaba num movimento disjunto: graus imediatos no começo, pequenos saltos intervalares no final.

\footnotetext{
7. "O efeito é o de desacelerar o movimento progressivo da melodia e atenuar os estímulos somáticos que conduzem às ações humanas, levando assim o ouvinte a identificar-se com um estado passional do 'ser' [...]. Os efeitos de tensão mais prolongados criados dentro de uma seqüência melódica tendem a favorecer um 'experimentar' introspectivo de estados de tensão psicológica, geralmente associados à separação amorosa ou à busca de um objeto de desejo" (TREECE, 2003, p. 338-9).

8. A “tematização" corresponde à repetição sistemática de um mesmo contorno melódico. "Através desse processo [...], a mobilização física do ouvinte é estimulada, o que é geralmente associado a gêneros de canções intimamente ligados à dança e ao movimento [...]. A tematização melódica presta-se naturalmente à tematização lingüística, ou seja, dá-se simultaneamente a materialização melódica e linguí́stica de uma idéia, como a exaltação de nações e tradições, a construção de personagens como a baiana, o malandro, ou a afirmação de valores universais tais como o bem e o mal, vida e morte, o prazer e o sofrimento" (TREECE, 2003, p. 339).
} 


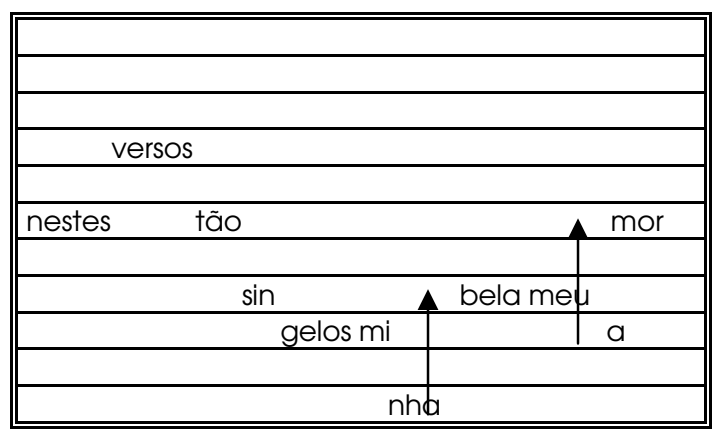

A terminação suspensiva anuncia que o percurso melódico continua, mas sobrevém a repetição do trecho. O retorno melódico é mais um dado que reforça o movimento de reflexão assinalado nos níveis discursivo e narrativo. E confirma a alternância de procedimentos (um decorrente do outro): à passionalização sucede a tematização.

Na segunda parte da melodia, o ponto de partida sofre uma pequena elevação e o perfil delineado atinge o ponto máximo da tessitura da canção. Trata-se de uma transposição, procedimento ligado aos valores remissivos já sugeridos pelos pequenos saltos presentes na primeira parte. A aceleração implicada na transposição convoca a remissão para proceder a um desdobramento melódico. É, assim, o percurso melódico que ainda se estende, de uma parte a outra. Os valores remissivos são imediatamente negados, a cada convocação, para a preservação dos valores ligados à continuidade.

De fato, após a transposição, voltam os graus conjuntos definindo o contorno melódico. Daí, como colocado acima, a remissão acelera a tonalização, dada a extensão da emissão, e ainda, pelo mesmo motivo, acrescenta um salto antes da última curva melódica dessa parte, que coincide com o ponto final da extensão melódica, processo que abarca a primeira e a segunda parte. Esse salto não é novidade no perfil, é mais a recuperação de um traço interno que aproxima essas duas partes da melodia, assim como a curva descendente, já exposta na primeira parte, que desfaz gradativamente o aumento de tensão trazido pela transposição.

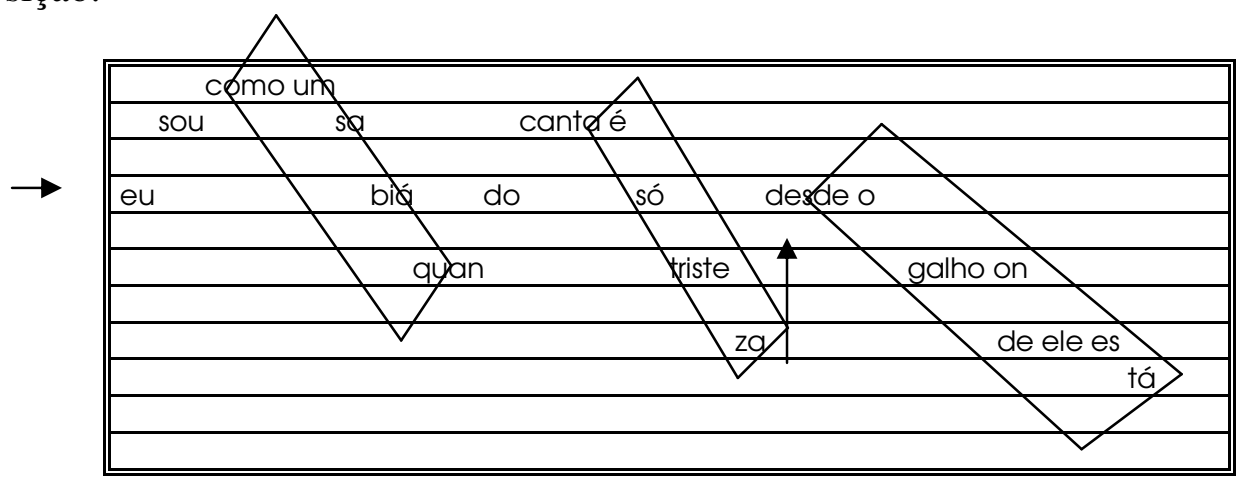

O refrão, dado o seu poder de concentração, oferece um resumo dos procedimentos. Temos aí a pequena curva ascendente dos perfis, partindo do limite inferior da tessitura e, assim, sendo minimamente tensionada, reaparece o salto que leva à inflexão terminativa dos perfis. Novamente, como na primeira parte, um mesmo perfil é repetido, e há a presença equilibrada da tonalização, marcante na curva ascendente, atenuada na curva descendente. 


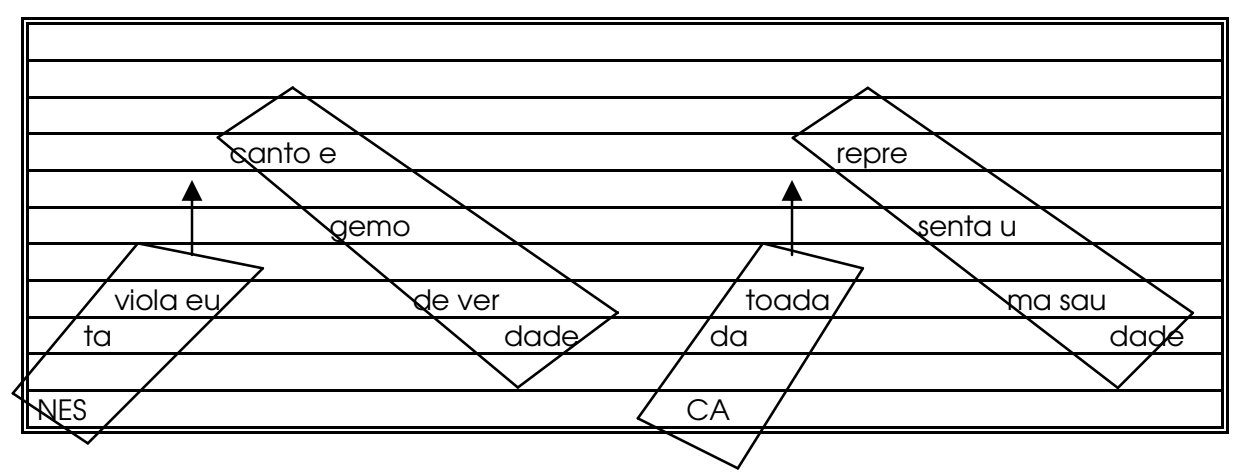

Extensamente considerada, a canção torna a revelar a predominância dos valores emissivos, predominância que convoca os valores remissivos, os quais têm de ser em seguida negados, compensados por articulações que preservem a emissividade dominante.

Assim, a primeira e a segunda parte vão dar no refrão, que responde pela concentração, isto é, pela involução melódica. Ao refrão há de suceder o desdobramento representado pela primeira e pela segunda parte melódica. Mas esse desdobrar-se da melodia é cauteloso, pois não pode confirmar os valores remissivos da aceleração que levariam à transformação radical do programa narrativo de estado. Por isso se faz em graus conjuntos, em repetições e gradações. A evolução se dá apenas internamente. A aceleração leva às mudanças, mas elas são contidas, externamente, pela involução que traduz a continuidade do estado.

A análise da melodia confirma a suposição de que os valores emissivos são em geral, mas não necessariamente, eufóricos (o contrário vale para os valores remissivos). Por isso há cabimento em pleitear um patamar de análise que considere o missivo à parte da foria. $\mathrm{Na}$ canção analisada, os valores emissivos são identificados à disforia, e os remissivos, à euforia. Daí a predominância dos primeiros nessa canção, que promove a reflexão depurativa de e sobre o estado disfórico de um sujeito que não encontra as competências necessárias para estabelecer um horizonte eufórico possível.

\section{Interpretações musicais}

A figurativização não chega a ter um papel marcante em "A tristeza do jeca", a não ser que se avente, numa espécie de devaneio, a interpretação dos pontos onde afloram os valores remissivos como os soluços que entrecortam uma cadeia discursiva dominada pelo choro. A figurativização aqui é negada e contida, pois, em se optando pela desaceleração, não interessa um procedimento que traga para a canção a velocidade da fala. Veja-se o caso do vocativo "minha bela, meu amor", por exemplo. Nas canções de melodia figurativa, o vocativo geralmente leva para fora dos contornos que definem um perfil melódico. Na canção analisada, pelo contrário, o vocativo integra-se ao fluxo, para que seus valores remissivos sejam afastados.

No entanto, a idéia de recuperar no canto as inflexões da fala (base da figurativização) importa nessa canção pela possibilidade que abre de reforçar o valor de verdade da instância da enunciação e, por extensão, do discurso enunciado. Todo o poder consolador atribuído ao canto depende da autenticidade do sujeito. Assim, ao acelerar ou fazer durar as tonalizações, ao deslocar ou manter os acentos das palavras, o intérprete faz a atenção oscilar ora para o canto ora para o cantor. 
$\mathrm{Na}$ interpretação de Pena Branca \& Xavantinho, os valores emissivos são mantidos sem excessos, com pouco destaque para mínimos trechos de aceleração, como no caso do primeiro verso, quando não há duração concentrada na passagem pela palavra "singelos" (e o estilo pausado e cadenciado da canção abre espaço para a tonalização da emissão, nesses pontos, numa interpretação que vise ao exagero). Já no caso de Passoca, identifica-se um esforço consciente para acelerar determinadas inflexões melódicas e fazê-las coincidir com as inflexões da fala.

Um exemplo do final da canção: "o choro que vai caindo". É nítida nesse trecho a diferença entre as interpretações. Pena Branca \& Xavantinho seguem o modelo emissivo latente na canção e cantam "o chorô", deslocando o acento e bandeando para o lado do canto. Passoca, por sua vez, desloca o acento melódico, fazendo-o coincidir com o acento original da palavra: "o chôro". No refrão também, Passoca, em vez de fazer durar a primeira sílaba da emissão, transfere parte de sua duração para a sílaba seguinte, equilibrando as durações, atenuando intensamente, mas expandindo extensamente, o investimento passional associado à tonalização.

Enfim, a utilização desses recursos de interpretação se justifica pela necessidade de dar veracidade ao discurso. A desestabilização do canto pela fala traz à tona a realidade e a autenticidade do sujeito que canta. Mostrando a fala por trás do canto, o intérprete revela o grão da voz, o corpo que canta atrás do canto.

\section{Considerações finais}

A canção guarda um segredo que afinal é marca de seu sucesso. A análise, se a tanto ousa, tenta tocar o coração desse mistério. Mas "A tristeza do jeca" é furtiva, ambígua. Pode-se dizer que o canto do caipira expõe um sofrimento que parece advir de sua própria condição existencial. A sociologia e a antropologia aqui teriam o que comentar. Bastava, aliás, pensar no modo de vida do "jeca", aquele personagem roído pela fome e pela verminose, descrito por Monteiro Lobato, para perceber que são muitas as condições adversas do homem do campo que justificariam plenamente o seu sofrer.

No entanto, por outro lado, há bem mais do que uma dor de origem "sóciohistórica" e política implicada no evento narrativo dessa canção. Na linguagem da semiótica, diríamos que há um dado intenso que repercute em todos os estratos de sentido por ela agenciados. Trata-se da alternância entre a enunciação e o enunciado, a qual no nível tensivo traduz-se como uma alternância entre forças emissivas (de contenção) e remissivas (de expansão), o que na melodia vem a dar nos processos de passionalização e tematização. Essa alternância que a análise semiótica vislumbra e decodifica pode ser a responsável pela ambigüidade da canção.

Por um lado, há a exposição de um sofrer, ou seja, a revelação de um estado passional. Ao ser tematizado, porém, tal estado é parte de uma celebração. A tristeza do jeca é de dar pena, mas também de se sentir orgulho, pela sinceridade e autenticidade que evoca e é a condição sine qua non de sua eficácia. A celebração da dor operada pelo canto é, sem dúvida, uma forma de exaltação dos valores morais do caipira. Por outro lado, o estado disjuntivo do enunciador pode ter causas bem mais palpáveis, como sugerido atrás, em nota de rodapé. É possível que toda essa exposição da tristeza esteja a servir ao propósito de seduzir o enunciatário (a amada), de modo que ao final o enunciador, num enredo que nos leva para fora da canção, possa entrar em conjunção com seu objeto de desejo. Como a canção é dominada pela figura da saudade, calcula-se que esse objeto, que depende da 
vontade do enunciatário, já tenha estado em poder do enunciador, por isso o certo talvez fosse falar em uma estratégia de reconquista.

Se assim for, a tristeza e o canto do jeca, a essa altura indissociáveis, são também uma engenhosa camuflagem, cujo encanto não pode ser negado, em face do real impacto da canção sobre gerações de ouvintes que seguramente a elegeriam como um dos clássicos da música caipira de todos os tempos.

\section{Referências Bibliográficas}

BARROS, D. L. P de. Teoria do discurso: fundamentos semióticos. 2. edição. São Paulo: Humanitas, 2001.

FONTANILLE, J.; ZILBERBERG, C. Tensão e significação. Tradução de. Ivã Carlos Lopes, Luiz Tatit, Waldir Beividas. São Paulo: Discurso Editorial/Humanitas, 2001.

PENA BRANCA \& XAVANTINHO. Violas e canções. CD produzido por Velas Produções Artísticas Musicais e Comércio Ltda. Gravação: estúdio Gravodisc-SP, 1993.

PASSOCA, in Violeiros do Brasil. São Paulo: Núcleo Contemporâneo et al., 1998.

TATIT, L. A canção: eficácia e encanto. São Paulo: Atual, 1986. (Série Lendo).

Semiótica da canção: melodia e letra. São Paulo: Escuta, 1994. (Coleção Plethos).

O cancionista: composição de canções no Brasil. São Paulo: Edusp, 1996.

Musicando a semiótica: ensaios. São Paulo: Annablume, 1998.

Análise semiótica através das letras. São Paulo: Ateliê Editorial, 2001.

TATIT, L.; LOPES, I. C. Ordem e desordem em “Fora da ordem". Teresa: revista de Literatura Brasileira, n. 4/5. São Paulo, 2003, p. 86-107. (Número especial "Literatura e Canção").

TREECE, D. Melodia, texto e $\boldsymbol{O}$ cancionista, de Luiz Tatit: novos rumos nos estudos da música popular brasileira. Teresa: revista de Literatura Brasileira, n. 4/5. São Paulo, 2004, p. 332-350. (Número especial "Literatura e Canção"). 